\title{
ASPEKTER AF KRISTEN GUDSDYRKELSE SET I LYSET AF HISTORISKE STUDIER OG RITUALSTUDIER ${ }^{1}$
}

\author{
Bernhard Lang
}

\begin{abstract}
ENGLISH ABSTRACT: This article, "Aspects of Christian Worship in the Light of Historical and Ritual Studies" offers a theoretical and historical investigation of early Christian rituals (the Lord's Supper, Biblical recitation, and the Lord's Prayer). According to principles of phenomenology of religion, the Lord's Supper is the result of a transformation of the more archaic animal sacrifice. In the perspective of Max Weber's thesis of progressive rationalization, public recitation of sacred scriptures appears as a breakthrough for intellectual religion. And following Émile Durkheim's understanding of religion as a social group's collective mind, the original context of the Lord's Prayer was the longing for the reconstruction of an independent Jewish state.
\end{abstract}

DANSK RESUME: Artiklen ligger i forlcengelse af Bernhard Langs bog Sacred Games (1997). Tre centrale dele i den tidlige kristendoms rituelle dimension: nadveren, Bibeloplcesning og bønnen Fadervor, analyseres vha. dels historiske, dels religionsvidenskabelige positioner. Ud fra klassisk og nyere religionsfcenomenologi kan nadveren ses som en transformation af slagtofre. Ud fra Max Webers tese om stigende rationalisering kan jødisk oplæesning af bibelske tekster ses som gennembrud for en intellektuel religionsform. Ud fra Émile Durkheims tese om religion som en social gruppes kollektive bevidsthed kan Fadervor ses som en oprindeligt politisk bøn om genoprettelse af en uafhæengig jødisk stat.

KEYWORDS: Ritual studies; Early Christianity; Phenomenology of Religion; Victor Turner; Max Weber; Émile Durkheim.

I mange år har jeg specialiseret mig i ritualstudier, og jeg valgte i sin tid kristendommen som den religion, jeg ønskede at fokusere på. Naturligvis stødte jeg i den forbindelse på Evelyn Underhills bog Worship på 350 sider, udgivet i 1936 i en serie med titlen "The library of constructive theology". Det var meningen, at dette bibliotek skulle udgive "studies of the main aspects of Christianity which will be intelligible and interesting to the general reader and at the same time may be worthy of the attention of the specialist" (Underhill 1936, ix).

Det var den samme læserkreds, jeg havde i tankerne, da jeg skrev min bog Sacred Games. A History of Christian Worship (1997). Mit mål var at nå frem til et bredtfavnende studium, der måske kunne være lige så elegant som Underhills, men mere rodfæstet i studierne af arkaiske kilder, med større opmærksomhed på moderne

\footnotetext{
${ }^{1}$ Oversat af Stine Bakkeløkken.
} 
ritualteori og historisk videnskab og med mindre andel i det, som Underhill mente var farerne ved overdreven formalisme, hvilket hun revsede som 'ritualisme'. I dette essay opsummerer jeg nogle af den kristne gudsdyrkelses vigtigste aspekter. Jeg har valgt at undersøge tre af gudsdyrkelsens elementære former: Den hellige nadver, bibelsk recitation og fadervor. Udover at være velegnet til historiske studier er disse former også velegnet til henholdsvis en fænomenologisk, en Weberiansk og en Durkheimiansk analyse. Derfor vil jeg her foreslå historiske tolkninger af hhv. den hellige nadver, bibelsk recitation og fadervor, og i hvert af tilfældene vil jeg endvidere kort kommentere visse omfattende spørgsmål vedrørende ritualtolkningen.

\section{Gudsdyrkelsens spirituelle aspekt: Nadveren som offer. En historisk og fænomenologisk tolkning}

For at forstå oprindelsen til og den oprindelige betydning af det, der blev kristendommens centrale ritualhandling - nadveren - må vi betragte offeret, som det blev praktiseret $i$ templet $i$ Jerusalem i det første århundrede e. Kr. Dyreoffer generelt - og ikke påskeofferet som et af dets særlige og specialiserede udtryk - er baggrunden for alle de elementer, hvoraf det nye ritual er dannet.

Der blev udført to væsentlige offerformer ved templet i Jerusalem: Offentligt og privat offer. Det typiske offentlige offer var det præstelige offer. Det blev udført hver morgen og hver eftermiddag, og det bestod $\mathrm{i}$, at man slagtede og brændte et etårigt lam; til gengæld forventede man, at Gud skænkede sin velsignelse til folket. Før det slagtede dyr blev brændt, udtalte en gruppe af fem præster en velsignelse over de mennesker, der så til fra tempelgården. Det er vigtigt at notere sig, at velsignelsen blev givet, før dyret blev brændt. Dette viser, at selve afbrændingen af dyret blot blev betragtet som en måde at skaffe det af vejen på og ikke som den centrale handling i ofringen. Den centrale handling var noget andet: fremførelsen af det døde dyrs blod og krop foran alteret. Denne præsentation var en symbolsk handling for at give, for at overbringe en gave til guddommen. Og efter at dette offer var fuldendt, gav Gud sin gave ved at skænke folket sin velsignelse. Med andre ord: Ofring betragtedes som en udveksling af gaver mellem menneske og Gud med mennesket som initiativtager.

Det private offer lignede det offentlige offer meget. Dog var det dyr, som skulle slagtes, i dette tilfælde ikke udvalgt blandt de dyr, der tilhørte templet, men blev medbragt af den lægmand, der sponsorerede offeret. Det private offer, der oftest blev bragt, var et todah, et takoffer. Den mest almindelige årsag til at bringe dette offer var et løfte: Ved sygdom eller nød kunne man love at ofre et takoffer, så snart krisen var ovre. Helbredelsen eller afslutningen på en økonomisk krise blev betragtet som Guds godgørende indgriben over for hans hengivne tilhænger. Takofferet fuldendte det løfte, som blev givet til Gud. Der var både tale om at tilbagebetale en gæld og om at fejre ens gode forhold til guddommen. Ved hjælp af Mishnah og andre gamle kilder kan proceduren rekonstrueres nogenlunde fuldstændigt. Man kan iagttage seks sekvenser: 
(1): Forberedelse. Den, der skal ofre (dvs. lægmanden), medbringer sine dyr og nogle andre gaver, inklusiv brød og vin, til templet og overgiver dem til en præst.

(2): Slagtning. Præsten slagter dyret, en handling der betragtes som adskillelse af 'blod' og 'legeme'. 'Blod' og 'legeme' er præstelige, tekniske termer.

(3): Fremførelse af blod ved alteret. Præsten kommer blodet i en skål foran alteret for at frembære det for Gud. Jeg formoder, at han samtidig med præsentationen fremsiger en formular: "Dette er NN's blod", hvor NN er navnet på offergiveren. Formularen identificerer offergiveren som den, der ofrer denne gave til Gud. Denne ofring fuldendes ved at stænke blodet på alle siderne af alteret.

(4): Fremførelse af legemet og brødet ved alteret. Offermaterialet bringes til alteret med en højtidelig gestus. Jeg antager, at præsten samtidig med fremførelsen ved alteret fremsiger disse ord: "Dette er NN's legeme", hvor NN er navnet på offergiveren. Derefter bliver dele af dyrets krop kastet på alterets brændende ligbål.

(5): Fremførelse og bortskaffelse af vinen. Præsten frembærer vinen ved alteret, hæver bægeret og anråber Guds navn. Den afsluttende ritualhandling består i udøsning af vinen ved alterets fod.

(6): Kommunionsmåltid. Offergiveren modtager kødet fra det slagtede dyr, og det spises umiddelbart efter.

Ritualet, som det her er rekonstrueret, har en velafbalanceret, symmetrisk opbygning. Den centrale handling er ofringen af det døde dyrs legeme og af brødet ved alteret (trin 4). Den handling er indrammet af to libationer; først af blod, derefter af vin. Det vigtigste offermateriale er det slagtede dyrs legeme og blod, som gentages i ublodig form med brødet og vinen.

Der findes ingen gamle kilder til de ord, som præsten bruger ved fremførelsen af offergaverne ved alteret. Her beror min rekonstruktion på de ord, som Jesus brugte i sit nyformulerede ritual: "Dette er mit legeme" og "dette er mit blod". Placeret i en konkret ritualsituation mister disse ord deres gådefulde kvalitet og lyder ganske naturlige. I en tidligere periode, da det var offergiveren og ikke præsten, som forrettede offeret ved alteret, kunne disse ord have været en offerfremførelsesformular. Når offergiveren trådte frem for alteret med det slagtede dyr, udtalte han måske ordene: "Dette er mit legeme" - det vil sige: Her fremfører jeg mit offerlegeme, det tilhører mig, og jeg lægger det på dit alter. Ligeså ville han ved ofringen af offerets blod sige "dette er mit blod" - det vil sige: Her tilbyder jeg mit offers blod.

Man kan bedst forstå Jesus' nye offer som en forkortet form af det just beskrevne ritual i seks trin. Jesus introducerede to væsentlige ændringer: (1) Han overførte ritualet til området uden for templet; som en konsekvens heraf måtte enhver handling, der 
involverede en præsts medvirkning, nødvendigvis udelades. Eftersom der ikke var nogen præst involveret, kunne der ikke slagtes dyr, ikke stænkes blod, og ikke brændes noget på alteret. (2) Jesus reducerede tempelritualet til dets ublodige del - ofringen af vin og brød. Det nye, ublodige ritual tjener trods den dybtgående ændring stadig det samme formål: at ære Gud med en gave og fejre ens gode forhold til det guddommelige; det tjener tillige som tak til Gud for modtagelse af ydelser. Derfor begyndte kristne snart at kalde det ved dets gamle navn eukharistia, den græske term for taksigelse. Den centrale rite, hvormed Gud blev æret, bestod i, at man løftede brød og vin og overrakte disse gaver til Gud ved at sige "dette er mit legeme - dette er mit blod". Det offer, som Jesus introducerede, bestod alene i selve fremførelsesriten, det vil sige opløftelsen og de ord, der ledsagede denne gestus. Hvis min rekonstruktion er korrekt, genindsætter den de centrale ord, som oldtidens jødiske præster udtalte ved offeroverrækkelsen. Mens templet blev ødelagt og det jødiske offer ophørte, overlevede disse ord - "dette er mit legeme - dette er mit blod" - som en af hjørnestenene i det kristne ritual helt til i dag. Ligesom det offer, de ledsagede og fuldendte, blev disse ord overført fra det jødiske tempel til det kristne bord.

Ifølge denne analyse fremstår nadveren som en reduceret form af offer, faktisk som et surrogatoffer, der ikke kræver en præsts tjenester eller et tempel, og som derfor kan udføres hvor som helst af en lægmand. De to elementer, der tilbydes - brød og vin - har muligvis også mindet om den passage i Genesis, hvor Melkisedek, "præst for Gud den Højeste", tilsyneladende anså brød og vin som specielt signifikante (1 Mos 14, 18). Det kan meget vel være, at brød og vin blev anset som de essentielle offergaver, man gav til Gud den Højeste.

Hvis man definerer nadverofferet som en gave bragt til Gud, falder min tolkning naturligt inden for religionsfænomenologiens område. I modsætning til Max Weber interesser fænomenologer sig ikke primært for konkrete tænkemåder og disses historiske og sociologiske udvikling på langt sigt; i modsætning til Durkheim ser de ikke på samfundet og social solidaritet som nøglen til at forstå, hvad religion egentlig handler om. Fænomenologer holder sig i stedet tæt op ad de troendes egen opfattelse af, hvad de gør. Med den fremragende fænomenolog Victor Turners egne ord er ritualet "prescribed formal behaviour for occasions not given over to technological routine, having reference to beliefs in mystical beings and powers" (Turner 1967, 19). Denne definition ligger til grund for mange af Gerardus van der Leeuws, Mircea Eliades og Turners egne undersøgelser af ritualer. Disse forfattere insisterer på, at en videnskabelig analyse ikke bør ignorere ritualets guddommelige modtager, og de deler en interesse for at etablere brede kategorier for religiøse handlinger, som forekommer i mere end én religion; ofring er en sådan handling. Nadveren, som den er beskrevet ovenfor, kan fænomenologisk beskrives som en substitut for et offer. I antropologisk litteratur kommer det klassiske eksempel på skånsom ofring fra Nuerne, et kvægvogtende folk i det sydlige Sudan. Når man ikke har råd til at slagte en okse, kan man bruge en lille agurk i stedet $i$ det mindste som en midlertidig udvej. Nuerne behandler agurken, som om den var et dyreoffer: Den fremføres og helliges, der siges en påkaldelse over den, og endelig 
'dræbes' den af spydet. Et endnu mere slående eksempel på surrogatoffer findes i Indien, for her har vi en fuldstændig parallel til, hvad der fandt sted i det Nye Testamente: Oprindeligt bestod det vediske offer af drabet på et dyr ledsaget af ris og byg; men senere blev drabet af dyret udeladt, og dyreofferet blev erstattet af ofring af korn (O'Flaherty 1998, 118).

Lignende eksempler kan anføres fra hele verden og fra andre perioder inklusiv Det Gamle Testamente og den tidlige jødedom. Tolkningen af nadveren, som den præsenteres her, kan derfor ses som eksempel på en fænomenologisk undersøgelse.

\section{Gudsdyrkelsens intellektuelle aspekt: bibelsk recitation og prædiken som intellektuelt ritual. En historisk og Weberiansk tolkning}

Romersk tradition priser Numa Pompilius, Romulus' efterfølger, som grundlæggeren af romersk religion og dens hellige ritualer. Numa lærte præsterne disse ritualer og bad dem om at videregive dem mundtligt. Ifølge legenden skrev han også bøger, der forklarede ritualerne og præsternes pligter. Men eftersom Kong Numa ikke troede på bøgers værdi, sørgede han for, at de blev lagt i en kiste og begravet ved siden af ham selv. Fire hundrede år senere vaskede et kraftigt regnskyl jorden væk, så kisten blev blottet. Efter at have undersøgt bøgerne aflagde en prætor ed for senatet om, at bøgerne ikke var egnede til at blive offentliggjort, og de blev derpå brændt.

Bibelsk tradition priser Moses som grundlæggeren af oldtidens israelitiske religion. Moses skrev - ligesom Numa - en hellig bog. Legenden beretter, at Moses før sin død betroede sin bog til præsterne. Tilsyneladende forblev bogen ulæst i lang tid. Mange hundrede år senere, da præsten Hilkija fandt den i Jerusalems tempel, blev kongen øjeblikkeligt gjort opmærksom på den. Kong Josijas efterfølgende religiøse reform begyndte med en offentlig oplæsning af hele pagtsbogen.

Mens disse to legendariske beretninger måske ikke i alle detaljer er historisk korrekte, reflekterer de uden tvivl to faktiske, historiske holdninger over for hellige bøger. Romerne havde ikke brug for tekster i en religion, hvor sædvane og mundtlig tradition sikrede den rituelle procedure. I modsætning hertil blev bøger i Israel i stigende grad vigtige. Ikke blot bestemte de den rituelle procedure, men de blev også selv en del af ritualet. Oplæsning af en hellig tekst, afholdelse af en prædiken eller en kombination af disse to (så prædikenen blev en forklaring på eller en refleksion i anledning af den tekst, der blev reciteret) træffes kun i få religioner såsom buddhisme og jødedom. Selvfølgelig har hver religion sine traditionelle fortællinger og ofte også specialister, der fortæller dem ved ceremonielle lejligheder. I de fleste religioner tilhører disse fortællinger imidlertid den mundtlige tradition: De læres ved at lytte til en historiefortæller, og de overleveres mundtligt til enhver, der har lyst til at lytte. En anden situation opnås, hvor den mundtlige tradition skrives ned og til sidst antager kanonisk autoritet inden for et 'tekstuelt fællesskab', det vil sige en gruppe af mennesker, hvis sociale aktiviteter er centreret omkring tekster, tekstfortolkere og tekstfortolkninger. Hvis en hellig skrift bliver en traditions centrale fokus, kan vi forsvare at kalde den en 'bogreligion'. I oldtidens mediterrane og nærorientalske verden var det kun jøderne, der samlede hellige 
skrifter og indstiftede et ritual, der indeholder deres recitation, oversættelse, forklaring og opbyggelige uddybning. "Alle andre lovgivere synes at have forsømt dette", bemærkede den jødiske historiker, Josefus (Contra Apionem 2,175). Det var inden for den tidlige jødedom, at kristendommen udsprang som et separat tekstuelt fællesskab.

Hvem var det, der inden for jødedommen opfandt og var den første til at praktisere den regelmæssige oplæsning fra hellig skrift? Desværre kan disse spørgsmål ikke besvares, for oprindelsen af jødedommens 'intellektuelle ritual' er dårligt dokumenteret. Vi har allerede nævnt Kong Josijas offentlige oplæsning af pagtsbogen, en hændelse der dateres til omkring 623 f. Kr., hvis man kan stole på den bibelske fremstilling. Man kan finde en anden tidlig reference til offentlig oplæsning af hellige bøger i Nehemias' Bog. Den oplæsning, der er nævnt her, blev foretaget af den lærde Ezra, en mand som introduceres som oldebarn til præsten Hilkija (Ezra 7,1), han der var medvirkende til Kong Josijas offentlige oplæsning tre generationer tidligere. Mens der synes at være et familiebånd mellem de to tilfælde af offentlig oplæsning, får vi desværre intet at vide omkring oplæsningens karakter som et fast fænomen ved gudsdyrkelse. En tredje gammel kilde, Deuteronomium, oplyser om den kontekst, i hvilken bibelske tekster kunne blive læst op. Her finder vi forestillingen om, at hver syvende år skulle være et braklægningsår, et helt år i løbet af hvilket al jord skulle forblive udyrket, så der ikke kunne bringes høst til huse. Ifølge bibelsk lovgivning var løvhyttefesten i et sådant år ikke en fejring af høsten, men en fejring af Guds hellige bog:

Hvert syvende år, på den fastsatte tid i gældseftergivelsesåret, ved løvhyttefesten, når hele Israel kommer for at se Herren din Guds ansigt på det sted, han udvælger, skal du læse denne lov op for hele Israel. Kald folket sammen, mænd, kvinder og børn og de fremmede i dine byer, for at de må høre den og lære at frygte Herren jeres Gud og omhyggeligt følge alle ordene i denne lov, for at deres sønner, som endnu ikke kender loven, må høre den og lære at frygte Herren jeres Gud, så længe I lever på den jord, som I skal tage i besiddelse ... (5 Mos 31,10-13).

Dette er den eneste bibelske passage, der refererer til en regulær offentlig oplæsning. Passagens arkaiske natur fremgår klart af, at en sådan oplæsning kun kan forekomme én gang hvert syvende år; endvidere er institutionen koblet sammen med en anden institution af tvivlsom anvendelighed - fejringen af braklægningsåret. Ikke desto mindre forekommer forestillingen om en regulær, offentlig oplæsning her, og den deuteronomistiske kontekst åbner for yderligere historiske analyser. Det er velkendt, at lovene, som er inkluderede i Deuteronomium, stammer fra assyrisk lovgivning, som de også imiterer stilistisk. Det kan meget vel være, at denne bogs kerne oprindeligt var sammensat som svar på Kong Assurhaddons arvefølgetraktat fra 672 f. Kr. Hvor den assyriske konge pålægger sine vasaller eksklusiv politisk loyalitet over for sig selv og sin søn, søger den israelitiske tekst at pålægge Israels sønner eksklusiv loyalitet over for Jahve, Israels Gud. Selvom vi ikke kender noget til en offentlig oplæsning af Assurhaddons skrift, har vi kilder, der viser den mesopotamiske lovbestemte sædvane med at påminde folket om deres forpligtigelser ved periodisk at læse lovskrifter op for dem. 
Et kileskriftsdokument fra det 14. århundrede f. Kr., der omhandler slaver og paladsets tjenere, afsluttes med denne instruktion: "Dette dokument skal læses op for dem hvert tredje eller fjerde år, så det ikke skal glemmes" (jf. Pfeiffer \& Speiser 1936, 103).

Traktatskrifter mellem en overherre og en betroet regent skulle læses op for den sidstnævnte "tre gange om året" (13. årh. f. Kr.; jf. Beckman, 1999, 91).

En anden hittitisk tekst fastsætter, at en traktat, der er sluttet mellem to regenter hittitternes konge og hurritterne - burde blive læst op i offentligheden: "Det skal i al fremtid læses op ofte for kongen af Mitanni og for Mitannis land og for hurritterne" (14. årh. f. Kr.; jf. Beckman 1999, 46).

Faderens testamente skulle ofte læses op for den hittitiske kronprins: "Denne tavle skal i al fremtid læses op for dig hver måned; så vil du lægge alle mine ord og al min visdom ind i dit hjerte" (16. årh. f. Kr.; jf. Sommer \& Falkenstein 1938, 15).

Alle disse kilder dateres til bronzealderen. De bevidner en meget gammel retsbrug, der uden tvivl også var gyldig i senere tider. Det er indlysende, at en regulær oplæsning af Moseloven for israelitterne og som en konsekvens heraf det intellektuelle ritual, som udføres i synagoger og kirker, i sidste instans stammer fra hittitisk og mesopotamisk retspraksis.

Da jeg første gang studerede religion i en akademisk kontekst, i 1960'erne, erfarede jeg den elegante distinktion mellem bogreligioner og kultreligioner, en distinktion, der er fremsat af Siegfried Morenz i hans bog Ägyptische Religion. Distinktionen syntes at antyde, at visse religioner, inklusiv oldtidens egyptisk religion, var baseret på ritualer, hvor jødedom og kristendom som bogreligioner helt og aldeles kunne undvære ritualer, fordi de tilhørte en slags religion, der simpelthen var vokset fra kultisk praksis. Imidlertid gik det snart op for mig, at selvom distinktionen påpegede noget væsentligt, var den misvisende. Den rette distinktion er ikke mellem bogreligion og kultreligion, men mellem intellektuel religion og ekstatisk religion. Ekstatisk religion er en veletableret term udviklet af antropologen Ioan Lewis. Hans bog Ecstatic Religion (1971) omhandler shamanisme og besættelse i etniske religioner. Det centrale argument er, at ekstatiske kulter rekrutterer deres medlemmer fra lavere klasser eller mere generelt fra dem, som føler sig underprivilegerede i forhold til den sociale elites velsignelser. For at sætte navn på den ekstatiske religions modsætning foreslog jeg i min bog Das tanzende Wort (1984) termen "intellektuel religion”. I modsætning til ekstatisk religion er den ikke udviklet af de underprivilegerede og de marginaliserede, men af dem, der placerer sig selv i centrum af det sociale og kulturelle liv, dvs. den uddannede elite. Det er meningen, at titlen Das tanzende Wort skal gengive Marrets maksime om, at primitive religioner ikke udtrykkes gennem tanken, men gennem dans; jeg påstod endvidere, at dansen, dog oftest metaforisk, endnu findes i kristendommen, og at det kun er den arkaiske tromme, der har måttet vige for det moderne hellige ord. Intellektuel religion og bogreligion er ikke andet end to termer for den samme virkelighed. Intellektuel religion privilegerer bogrelaterede ritualer, særligt oplæsning af skriften og fortolkende prædiken. I intellektuelle religioner er den religiøse specialist en intellektuel - den lærde 
mand, den vise, den skriftlærde. Han er specialist i den hellige bog, dens sprog, dens tolkning og anvendelse. Han ved, hvordan man får modstridende passager i skriften, doktriner eller retslige bestemmelser til at stemme overens, og han udfordres muligvis til at opstille retslige eller dogmatiske systemer på baggrund af urgamle bøger. Max Weber var vel vidende om det bidrag, som arkaisk, intellektuel religion gav til den vestlige rationaliseringsproces. Ifølge Weber gjorde jødedommen med dennes understregning af lov og lærdom religion til et intellektuelt anliggende, og den bidrog således til den typisk vestlige intellektualisering af det sociale liv og dets mange forgreninger. Skønt den skriftlærde var involveret i traditionel lærdom, bidrog han ikke desto mindre til den afgørende udvikling af højere lærdom, først i klostre og siden hen i middelalderens universiteter. Vestlig rationalitet, argumenterede Weber, omfatter et stærkt religiøst element, der i sidste ende er afledt af Bibelen.

Distinktionen mellem intellektuel og ekstatisk religion er til stede i Bibelen selv. Den relevante passage er episoden med Moses og Guldkalven. Mens Moses var borte og brugte en tid alene på Guds bjerg for at modtage lovtavlerne, gjorde israelitterne et afgudsbillede i skikkelse af en guldkalv. De glemte alle intellektuelle anliggender, mens de dansede omkring dette hellige objekt og fejrede en orgiastisk og ekstatisk kult, en kult som involverede at spise, drikke, lege, synge, danse, råbe og lave larm (2 Mos 32,6.17-19). Da Moses vendte tilbage, blev han vred:

Da Moses kom nærmere til lejren og så tyrekalven og dem, der dansede, flammede hans vrede op, og han slyngede tavlerne til jorden ved bjergets fod og knuste dem. Derpå tog han kalven, som de havde lavet, og brændte den; han knuste den til støv (2 Mos 32,1920).

Til slut blev Moses dog i stand til at genetablere den offentlige orden og sin egen intellektuelle autoritet. I en af renæssancekunstens mest berømte skulpturer har Michelangelo fanget Moses' karakter som leder af et uværdigt, uskolet folk. Mens han knuger de to tavler i sine arme, synes han at sidde på et bjerg, hvorfra han med ringeagt og foragt kigger ned på sit folk. Hvad end Michelangelo havde i sinde, er dette den fortolkning, som Sigmund Freud giver i et berømt essay. Freud fornemmede, at Mosesfiguren rummer en skriftmæssig, intellektuel religions autoritet, en religion der hverken er let at forstå eller let for masserne at praktisere.

\section{Gudsdyrkelsens politiske aspekt: Fadervor. En historisk og Durkheimiansk tolkning}

Fadervor - den ældste og hyppigst reciterede kristne bøn - er i evangelierne overleveret $i$ to versioner og tilskrives Jesus (Luk 11,2-4 og Matt 6,9-13). Kun to af dens bønner er umiddelbart forståelige for den, der reciterer teksten i dag: bønnen om dagligt brød og bønnen om forladelse af skyld. De andre bønner - om helligelse af det guddommelige navn, Guds riges komme, beskyttelse mod fristelse og så videre - er uigennemskuelige, og de udgør ligesom teksten som helhed en udfordring for en historisk undersøgelse. De 
første tre bønner ('helliget blive dit navn', 'komme dit rige', 'ske din vilje') må oversættes fra et sprog, der i overensstemmelse med høflig praksis ikke direkte fortæller en overordnet, hvad han bør gøre; hvis vi ignorerer den høflige stils tilbageholdne karakter, får vi: 'lad dit navn hellige', 'lad dit rige komme', 'lad din vilje ske'. Men selv denne ordlyd har mistet noget af sin oprindelige uigennemskuelighed. Bønnens gådefulde natur skyldes en lingvistisk kode, der kaldes 'restringeret' - en stil der, mens den forudsætter et repertoire af traditionelle udtryk, kommunikerer sin betydning til dem, der som en selvfølge forstår dens ord og dens yderligere implikationer. Typisk bruges denne form for sprog af præster, skriftlærde og dem, som er involveret i udformningen af ærværdige traditioner, kort sagt af en gruppe der er fortrolig med et specialiseret videnskorpus, som vil forblive fremmed for uindviede. Udsagn, som gives i den restringerede kode, synes klare for den indviede, men forvirrende for den uindviede. Den modsatte lingvistiske stil involverer en 'elaboreret kode'; denne stil undgår kondenserede udsagn og brugen af teknisk terminologi. Forfattere, der søger at gøre specialiseret viden tilgængeligt for den almene læser (det vil sige den uindviede), betragter den elaborerede kode som deres ideal. Forskellen mellem de to lingvistiske koder kan illustreres ved at sammenligne ønsket om Guds riges komme i to bønner. I den elaborerede kode kunne bønnen have følgende ordlyd:

Forbarm dig over os, Herre, du som er Gud over alle ting. Udbred frygten for dig over alle folkeslag; løft din hånd mod de fremmede folk, og lad dem se din magt ... gør det af med modstanderen og udryd fjenden ... Før alle Jakobs stammer sammen, og giv dem det land i eje, de har haft fra begyndelsen (Sir 36,1-3.9.13).

Det er klart, hvad denne bøn er rettet mod: enden på Israels underdanighed i forhold til supermagter (seleukiderne og senere romerne) og den følgende genopretning af Israel som en uafhængig stat, hvor de, som vender tilbage fra diasporaen, kan finde ejendom og et hjem. I fadervor udtrykkes den samme bøn ved at sige: "Vor Fader - komme dit rige:" Denne kondenserede version bruger ikke blot den traditionelle term '(Guds) rige' (som undgås i elaboreret sprog); den formulerer også den aktuelle bøn på en behersket, indirekte vis, for "komme dit rige" betyder: 'etabler dit rige!' eller 'genopret dit rige!'.

Brugen af den restringerede kode - en stil der irriterer den moderne kirkegænger og udfordrer historikerens opfindsomhed med hensyn til tolkning - giver mening, når man tager Fadervors oprindelige hjemsted i betragtning. Ifølge Lukasevangeliet var denne bøn aldrig ment som noget, alle troende skulle bruge; i stedet var det meningen, at det skulle tilhøre den lille kreds af Jesu nærmeste disciple. Det var dem, der spurgte Herren om, hvordan man skulle bede, og det var til dem, Fadervor blev givet. Konteksten synes at bekræfte, at Jesus frem for at udtænke en ny bøn brugte et eksisterende sæt bønner, højst sandsynligt et sæt der allerede blev brugt, og som sikkert havde sin oprindelse i kredsen omkring Johannes Døberen. I min bog Sacred Games har jeg foreslået, at man overvejer Johannes Døberen som ham, der udtænkte Fadervor, og Karlheinz Müller - en autoritet på området om jødisk gudsdyrkelse - har for nylig understøttet hypotesen med flere argumenter. Den kristne bevægelse har ikke blot arvet sin sakramentale 
initiationsrite fra Johannes Døberen, men også sin første bøns ordlyd. I modsætning til den tidlige tradition har historisk forskning ingen grund til at skjule kristendommens gæld til dens førkristne grundlægger. Dog er det muligt, at Johannes Døberen ikke var den første til at bruge Fadervor. Forventningen om Guds rige og den urolige situation, som gengives i bønnen, kan pege tilbage til en endnu tidligere oprindelse. Under det Gamle Testamentes seneste fase inkluderer folk typisk tre elementer i deres bønner: en klage over Israels skæbne; en bøn om tilgivelsen for de synder, der er ansvarlige for denne situation; og en bøn om guddommelig indgriben på vegne af folket (Es 63,7-64, 11; Neh 1,5-11; Dan 9,4-19; Bar 2,11-3, 8; se også den jødiske Attenbønnen, Amidah). De to bønner, der ikke forekommer i denne tradition - bønnen om brød og bønnen om ikke at blive ledt i fristelse - afspejler højst sandsynligt forventningen om en periode med alvorlig krise, der vil gå forud for oprettelsen af riget. Sekvensen "stor modgang Guds jødiske rige" kan findes i Daniels Bog (Dan 7,21.25; 7,14.27) som et ekko af seleukidekongen Antiokus IV's forfølgelse af fromme jøder. Fadervors ord kan derfor være blevet udtænkt under den seleukidiske forfølgelse af de fromme troende (167-164 f. Kr.), dvs. at Fadervor kan være opstået i de samme kredse, som var ansvarlige for de apokalyptiske passager af Daniels Bog, med hvilke Fadervor deler forventningen om Guds riges komme. Åbenbart er Danielsk apokalyptik og Fadervor født som tvillinger. Forfølgelsens kontekst kan muligvis forklare bønnens kortfattethed og gøre rede for betydningens indkodede natur.

Fadervor (i Matthæus' version) kan parafraseres således: 'Vor himmelske fader, genopret dit navns hellighed, kom og genopret dit kongelige herredømme, handl i overensstemmelse med din beslutning og dit løfte. Giv os, hvad vi har brug for i dag. Tilgiv os vores skyld i forbindelse med afgudsdyrkelse og frafald, som også vi tilgiver vore fjender, der har besejret os. Fri os fra dommens dag (eller prøvelsens dag), og frels os fra alt ondt'. Begyndelsen af bønnen kan udtrykkes lidt mere præcist: 'Genopret dit navns hellighed ved at genoprette dit kongerige - den jødiske stat - lige som du har lovet'. Den centrale bøn om tilgivelse er relateret til skyld i forbindelse med afgudsdyrkelse og frafaldet fra den sande, eksklusive gudsdyrkelse - en forbrydelse der fremprovokerer guddommelige vrede, og som har ledt til ødelæggelsen af oldtidens jødiske stat. Når Gud har tilgivet denne forbrydelse, vil han genoprette sit jordiske kongedømme, så Guds folk atter organiseres i deres egen stat. Selvom visse detaljer fortsat er usikre for den historiske undersøgelse, er den oprindelige betydning af Fadervor tydelig nok: Det er en bøn fremsagt i en urolig tid, som blev opfattet som en eskatologisk prøvelse.

I den tidlige menighed og uden tvivl allerede på Jesu tid var denne bøn ved at miste sin oprindelige betydning, selvom den oprindelige ordlyd blev bevaret. Når de første kristne udtænkte deres egne bønner, bad de ikke Gud om etableringen af en stat; de bad derimod indtrængende om de hedenske autoriteters helbred og trivsel (1 Klemens Brev 60-61; ca. 100 e. Kr.); deres ideal var et uforstyrret, upolitisk liv i det romerske rige. Hvordan de tidlige Jesusbevægelser og den uudviklede menighed forstod 'Guds rige', kan ses i den ældste Jesus-tradition og i Lukasskrifterne (Lukasevangeliet og Apostlenes 
Gerninger). Jesus forestiller sig her ikke det guddommelige kongedømme i primært politiske termer; for ham er Guds rige nær, og det begynder uanseligt at manifestere sig selv - hvor synd tilgives, de syge helbredes, og folk finder deres tro hos Gud. Bemærkningen om et genoprettet jødisk rige angår ikke ham; tilsyneladende består Guds riges komme i fornyelsen af individuelle, menneskelige liv. Lukas diskuterer eksplicit problemet om Guds politiske rige i sammenhæng med et fyrre dages lang samvær mellem den genopstandne Herre og apostlene (ApG 1,3-8). Guds intervention i historien ses på to måder: Gud vil genoprette den jødiske stat, men tidspunktet afsløres ikke for apostlene; det kristne fællesskab har førstehåndserfaring med den guddommelige ånd som en kraft, der leder kirken.

Hvordan ville Durkheim have reageret på vores læsning af Fadervor? Når de australske aboriginere fester med fællesdanse, så er deres guder til stede og skænker deres gaver, hvor den centrale gave er samfundet selv. Ifølge Durkheims Formes élémentaire de la vie religieuse (1912) er guderne det sociale livs sjæl. Uden guderne ville det sociale liv ikke eksistere; omvendt ville ingen tro på guderne, hvis det ikke var for det sociale liv. Hos Durkheim er Gud og den sociale gruppe nærmest identiske eller rettere, forestillingen om Gud repræsenterer samfundet i forvandlet form. I overensstemmelse med sin præference for kollektive ideer ville Durkheim uden tvivl påskønne Fadervor som en bøn fra et folk, hvis sociale og politiske liv var disintegreret, og som nu længes efter, at det bliver genoprettet. Durkheim ville uden tvivl tilslutte sig min idé om, at Guds vilje ("ske din vilje") sigter mod at retablere den disintegrerede sociale og politiske gruppe, for det er, ifølge Durkheim, netop hvad religion handler om. Hvis bøn i det hele taget giver mening, burde den være patriotisk og sigte mod at give sociale og muligvis det politiske liv ny styrke. Durkheims entusiasme ville formentlig ikke strække sig til Jesusfiguren selv, hvis kongedømme ikke er af denne verden, og som sikkert ikke vil manifestere sig selv i folkets kollektive liv.

I det følgende vil jeg kommentere et vigtigt og generelt overset aspekt af det sociale områdes betydning - ideen om, at Guds rige vil være en eskatologisk eller endegyldig størrelse, der ikke længere kan rystes af menneskelige eller dæmoniske kræfter. I Daniels Bog er Guds rige bestemt 'endegyldigt' i denne forstand, og vi ser de samme forestillingsrækker i Paulus' breve og i Johannes' Åbenbaring. Fra et Durkheimiansk perspektiv ligner forestillingen om endegyldig stabilitet, Guds riges uophørlige natur, den uundgåelige konsekvens af selve den religiøse tro. Hvis Gud er almægtig og evig, så må det samme også gøre sig gældende for samfundet forstået som Guds rige. Trods logikken yder denne Durkheimianske optik ikke den religiøse histories fakta retfærdighed.

Ifølge Jonathan Z. Smith må man skelne mellem to forskellige mentaliteter i senantikkens middelhavsreligioner. Smith benævner dem henholdsvis 'traditionel' og 'utopisk', en terminologi som jeg vil bruge i det følgende. Ifølge traditionel religion har Gud eller guderne i en mytisk fortid ordnet verden, og verden var i sit inderste væsen uforanderlig. Dog har det altid været en plaget verden. Traditionel religion ser det menneskelige liv, samfund og stat som essentielt skrøbelige. Ved oversvømmelse og 
tørke, hungersnød og pest, nederlag i krig, undertrykkelse af de fattige osv. truer og skader dæmoniske kræfter den. Kampmyter forklarer, hvordan en guddommelig kriger holder kaosmagterne på afstand og muliggør verdens overlevelse. Naturligvis ophører kampen aldrig, for efter hvert nederlag fornyer kaosmagterne på den eller den anden måde sin styrke. På et praktisk niveau betyder dette, at social integritet skal opretholdes via et stadigt arbejde udført enten af mennesker eller af Gud eller som et samarbejde mellem begge. Hyppigt foretrækker traditionel religion den 'thaumaturgiske' reaktion på det onde. Denne 'mirakelvirkende' reaktion fokuserer på individets håb om befrielse fra aktuelle, specifikke problemer. Bønnen om overnaturlig hjælp er personlig og lokal, og dens virkning er magisk. Frelsen er øjeblikkelig; men den gælder kun den givne sag og andre lignende sager. Den består i helbredelse, sorglindring, genoprettelse efter tab, beroligelse, forhindring og undgåelse af katastrofer og sommetider også løftet om liv efter døden. Det er en 'helliggørelsesreligion', som er indstillet på udbedring af ting, der er malplacerede: korrektion af uret, renselse og helbredelse genopretter tingenes ideelle tilstand og frembringer sunde sociale, politiske og individuelle menneskelige kroppe på bestemte steder, som $\mathrm{fx}$ i det hellige land Palæstina.

Smith stiller den traditionelle religion, som han også kalder 'stedsreligion' (han benævner den 'lokativ'), i modsætning til en 'utopisk' religionsform, som er det andet paradigme, der skal tages i betragtning her. I utopisk religion er verden langt fra uforanderlig. Den bevæger sig gennem uophørlig konflikt mod et endeligt, fredfyldt stade - kosmos uden kaos. Den essentielle myte beretter om en tid, hvor den øverste gud endeligt, i en gigantisk kamp, vil bekæmpe kaosmagterne og deres menneskelige allierede og udrydde dem for evigt og indføre en verden, der er absolut god. Som den græske term 'utopisk' antyder, er selve stedet ikke længere et stridspunkt. Snarere end at være optaget af korrektion af uret, renselse og helbredelse venter man på en voldsom omvæltning, ud af hvilken en ny universel orden vil opstå - en orden der siden hen vil herske i evighed i himlen eller på jorden eller i begge verdener på samme tid.

Der er eksempler på begge religionstyper i Bibelen. Johannes Døberen og Jesus synes at repræsentere den traditionelle type, for deres projekt er helbredelsen af det palæstinensiske samfund, enten ved at retablere den jødiske stat eller ved at helbrede enkeltindivider. I modsætning hertil er Paulus og Johannes’ Åbenbaring ikke længere interesserede i det lokale projekt med at reparere et skadet socialt og politisk system. Paulus fokuserer på adskillelse fra verden og på at være sammen med Kristus i himmelen. Johannes' Åbenbaring beskriver i detaljer den endelige universelle kamp mellem Gud og mørkets kræfter og ser frem mod Guds endelige sejr. Dette skrift kulminerer i beskrivelsen af den endelige tilstand, hvor der hersker fred, og i hvilken alle helgenerne fryder sig over deres herre i det ny Jerusalem.

Med sin understregning af politisk frigørelse (Johannes Døberen) og eksorcistisk helbredelse (Jesus) reflekterer Fadervor den traditionelle religions interesse for helliggørelse. I senere kristendom kunne den naturligvis få en utopisk betydning. Inden for en kontekst, hvor man forventer, at Gud vil ødelægge de onde kræfter en gang for alle, kan man se "komme dit rige" og "fri os fra det onde" som en forventning om etableringen af 
Guds evige, universelle herredømme. Denne forventning om alt det ondes endeligt, som deles af Paulus og af Johannes’ Åbenbaring, har bestemt haft indflydelse på den måde, hvorpå mange af de første kristne har forstået Fadervor; og dog virker det, som om Jesus ikke selv gav sit budskab en sådan utopisk ramme. Selvom han muligvis håbede på at kurere det jødiske samfund som helhed, overskred han aldrig håbet om den øjeblikkelige, dog midlertidige, triumf over det ondes kræfter. Han forblev en lokal helbreder. Sagt på den Durkheimianske måde: Han synes aldrig at have troet på et evigt, perfekt socialt system.

\section{Konkluderende observationer}

Som opsummering: De tre elementære former for kristen gudsdyrkelse, som vi har studeret, kan spores tilbage til tre forskellige kontekster. Nadverens sakramente gengiver præstelige forestillinger om offer som gavegivning; det intellektuelle bibelrecitationsritual og prædikenen afspejler juridisk tænkning og praksis; Fadervor er rodfæstet $i$ en oplevelse af politisk afhængighed af et fremmed overherredømme. Hvordan forholder de tre aspekter af kristen gudsdyrkelse - nadverens sakramente, bibelsk recitation og Fadervor - som er blevet diskuteret her, sig til hinanden? Og hvordan forholder de sig til de andre "sacred games", som jeg har beskrevet i min bog: spirituel ekstase, sakramente og lovprisning? Naturligvis har jeg stillet mig selv dette spørgsmål ganske ofte, og jeg tror, jeg kan komme med et svar. Mens visse teologer kan være tilbøjelige til at se et kompliceret system som grundlag for gudsdyrkelse, argumenterer jeg for, at der ikke er noget vidtfavnende system. Hvis der fandtes et system, ville det være en kunstig konstruktion, som hører til i den lærde spekulations- og fortolkningsverden, men ikke i den egentlige praksis for selve den kristne gudsdyrkelse. Med andre ord: kristen gudsdyrkelse er en samling af inkommensurable, heterogene, men dog på ingen måde modstridende og uforenelige sacred games. Det forstås bedst med patchworkanalogien - som noget der er skabt af oprindeligt uafhængige stykker, der er stykket sammen og som kommer til at danne noget nyt og unikt. Eller som Claude Lévi-Strauss muligvis ville sige: den kristne liturgist er en bricoleur, som kombinerer forskellige traditionelle elementer for at kunne konstruere noget brugbart og nyttigt.

Som støtte for denne påstand kan jeg henvise til det faktum, at de ældste kristne kilder ligesom alle græsk-romerske kilder til religiøse ritualer sjældent bruger et vidtfavnende udtryk til at beskrive deres rituelle liv. Det mest almindelige udtryk for ritual, ta hierá, betyder "de hellige handlinger"; det er kun brugt én gang i det Nye Testamente - $\mathrm{i}$ en paulinsk passage der refererer til "de, der gør tjeneste ved alteret" $\mathrm{i}$ Jerusalems tempel $(1$ Kor 9,13). Udtrykket synes ikke at være blevet brugt til at betegne kristen gudsdyrkelse. I hedensk litteratur er enkeltordsbetegnelser med vidtfavnende betydning - såsom ta hierá - også relativt sjældne. Den mest almindelige måde at henvise til religiøse ritualer på i oldtiden er ved at opliste dets repræsentative handlinger. Typiske beskrivelser kan findes hos Plutark: 
Again, the very legislation that Colotes praises provides first and foremost for our belief in the gods, ... using hope as well as fear to establish in them by means of prayers, oaths, and omens, a lively sense of the divine. In your travels, you may come upon cities without walls, writing, king, houses, or property, doing without currency, having no notion of a theatre or gymnasium; but a city without holy places and gods, without any observance of prayers, oaths, oracles, sacrifices for blessings received or rites to avert evil, no traveller has ever seen or will see (Plutarch, Moralia 1125 D/E).

The most pleasant things that men enjoy are festal days and banquets at the temples, initiations and mystic rites, orgiastic rites and prayer to the gods as well as prostrations (Plutarch, Moralia 169 D).

En lignende passage kan findes i Det Nye Testamente:

De holdt fast ved apostlenes lære og fællesskabet, ved brødets brydelse og ved bønnerne [proseukhai, skal sandsynligvis gengives med "bønnemøder"]. ... De kom i enighed i templet hver dag; hjemme brød de brødet og spiste sammen, og jublende og oprigtige af hjertet priste de Gud og havde hele folkets yndest (ApG 2,42.46-47)

I alle disse tekster ser vi eksempler på det, som de gamle kalder enumeratio. Dette vigtige stilistiske greb tjener til at belyse og illustrere et faktum ved at opliste dets karakteristiske dele eller ved at sidestille detaljer. Bibellæsere er velkendte med denne anordning: tænk blot på den række af mennesker, der pinsedag hører på St. Peters prædiken (ApG 2,8-11) eller Paulus' katalog over sine lidelser (2 Kor 11,24-27). Ved opremsningens hjælp undgik forfatteren en farveløs og begrebsmæssig reference til det, som vi vil benævne som "religiøst ritual" eller "kult" eller "sacred games", og fremmanede i stedet ritualernes verden gennem opremsningen af en serie af repræsentative ritualhandlinger og institutioner. Imidlertid ville vi undervurdere denne procedure, hvis vi ser den som et blot stilistisk greb, der tjener til at oplive en tekst. Opremsningsdiskursen afslører en bestemt indfaldsvinkel til virkeligheden, der er karakteristisk for arkaisk mentalitet. Arkaiske kulturer havde tilbøjelighed til ikke at begribe og navngive det, som for os synes at være organiske entiteter; i stedet tilegnede de sig virkeligheden stykke for stykke simpelthen ved at sidestille, hvad de så og forstod. Denne metode frasiger sig det yderligere skridt, der vil koordinere de tilføjede indsigter eller aspekter med henblik på at forme et hele og danne et forståeligt begreb til at betegne det. I adskillige publikationer, der bevæger sig en del ud over ægyptologisk forskning, som er hendes oprindelige felt, har Emma Brunner-Traut studeret den præ-moderne måde at tænke og opfatte på; hun foreslår at kalde det 'aspektivisk tænkning' (“aspektivisches Denken"), en intellektuel stil der fokuserer på aspekter frem for komplette realiteter. I denne måde at tænke på kan komplette helheder kun erkendes og tilegnes skridt for skridt i form af tilføjede aspekter. Hovedidéen kan nemt ses at gælde både for arkaisk egyptisk kunst og for vore egne børns tegninger: De portrætterede objekter og personer er ikke afbildet som set af en bestemt tilskuer fra et bestemt sted; i stedet er de blot sammenstillet, som om hvert objekt er set separat og fra en separat, privilegeret 
placering; selv menneskets kropsdele - hovedet, skuldrene, armene og så videre - er afbildet separat, og er ikke integrerede, så de danner en synlig enhed. Der er ikke noget centralt punkt, der organiserer billedet.

I et nyligt udgivet essay (Lang 2002) har jeg samlet mange passager fra arkaisk græsk og romersk litteratur og inskriptioner, kristne såvel som ikke-kristne, der vedrører ritualer. I disse passager er der to forskellige retninger: en der sigter mod abstrakt konceptudvikling og derfor kommer i nærheden af den moderne forestilling om religiøse ritualer; og en anden, modstillet, retning der er mærket af og holder sig inden for den additive måde at erkende og tænke på. Holistisk erkendelse sigter mod det omfattende, abstrakte koncept; i modsætning hertil bevæger additiv perception sig mod opremsning og oplistning af levende detaljer, der afslører et aspektivistisk tankesæt. Begge poler - abstrakt konceptudvikling og levende afbildning - har fordele og ulemper. Abstrakte idéer fremmer konceptuel tænkning, mens opremsning fodrer fantasien. Set fra den abstrakte tænknings perspektiv forekommer opremsning primitivt og unødvendigt kompliceret. Set fra den additive tænknings standpunkt synes den abstrakte tilgang at være utilstrækkelig til at behandle virkelighedens kompleksiteter, for "abstract thinking destroys the sensuous image" (Erich Rothacker). Den stil, der foretrækker opremsning, frasiger sig det abstrakte konceptudviklings ødelæggende skridt. Den forebygger, at idéer så som ta hierá vil dominere og opløse rituallivets konkrethed. Den aspektive, sammenstykkende tilgang tilbyder en vigtig belæring, for den retfærdiggør den analyse af kristen gudsdyrkelse, der foreslås i dette essay.

\section{Litteratur}

BECKMAN, GARY

1999 Hittite Diplomatic Texts, Society of Biblical Literature, Atlanta, Ga.

LANG, BERNHARD

1984 Das tanzende Wort. Intellektuelle Rituale im Religionsvergleich, Kösel, München.

1997 Sacred Games. A History of Christian Worship, Yale University Press, New Haven.

LEWIS, IOAN M.

1971 Ecstatic religion. An Anthropological Study of Spirit Possession and Shamanism, Penguin, Harmondsworth.

MORENZ, SIEGFRIED

1960 Ägyptische Religion, Kohlhammer, Stuttgart.

O'FlaHERTY, Wendy DONINGER

1998 Other People's Myth, Macmillan, New York.

PFEIFFER, R.H. \& E.A. SPEISER

1936 One Hundred New Selected Nuzi Texts, Yale University Press, New Haven.

SOMMER, F. \& A. FALKENSTEIN

1938 Die hethitisch-akkadische Bilingue des Hattusili I. [Labarna II.], Abhandlungen der Bayerischen Akademie der Wissenschaften. Phil.-hist. Abt. NF 16. 


\section{Bernhard Lang}

TURNER, VICTOR

1967 The Forest of Symbols, Cornell University Press, Ithaca, NY.

UNDERHILL, EVELYN

1936 Worship, Nisbet, London.

Bernhard Lang

Universitätsprofessor, Dr. theol.

Universität Paderborn 